Katarzyna ŻODŹ-KUŹNIA

Poznań

Janusz WIŚNIEWSKI

Poznań

\title{
Dynamika wzajemnych relacji między Unią Europejską a Chińską Republiką Ludową na początku XXI wieku
}

B ezprecedensowy wzrost znaczenia relacji wzajemnych między Unią Europejską a Chińską Republiką Ludową, realizowanych w wymiarze partnerstwa strategicznego na początku drugiej dekady XXI wieku ma kluczowe znaczenie dla ewolucji współczesnego systemu międzynarodowego. Na pierwszym planie wzajemnej kooperacji sytuuje się ciagle płaszczyzna gospodarcza, przede wszystkim z uwagi na potencjały ekonomiczne obu partnerów i zakres ich wzajemnych powiązań. Dynamiczny rozwój unijno-chińskiej współpracy gospodarczej jest jednym z zasadniczych trendów w międzynarodowych stosunkach gospodarczych. Państwo Środka jest obecnie najważniejszym partnerem gospodarczym jednoczącej się Europy w Azji i drugim po Stanach Zjednoczonych w skali globu. Dla Chin Unia jest największym partnerem gospodarczym na świecie i drugim po Hongkongu źródłem bezpośrednich inwestycji zagranicznych. Istotny aspekt wzajemnych relacji stanowi współpraca sektorowa. Z kolei dialog polityczny, pomimo podjętych środków w kierunku jego intensyfikacji i pogłębienia znajduje się ciągle w fazie in statu nascendi. Na tej płaszczyźnie uwidaczniają się wzajemne antagonizmy i różnice zdań, zwłaszcza w kwestiach standardów demokratycznych oraz przestrzegania praw człowieka.

\section{Instytucjonalny wymiar wspólpracy}

Stosunki dyplomatyczne między Europejską Wspólnotą Gospodarczą (EWG; European Economic Community - EEC) a ChRL zostały ustanowione w maju 1975 roku. Pierwszy układ o współpracy gospodarczej zawarto 2 maja 1978 roku. W lipcu 1978 r. miało miejsce pierwsze spotkanie Wspólnego Komitetu w Pekinie. W 1985 roku zawarto nowy układ o handlu i współpracy (EC-China Trade and Economic Cooperation Agreement) rozszerzający dotychczasowe jej ramy. Od 1988 roku funkcjonuje w Pekinie delegacja Komisji Europejskiej. W związku z wydarzeniami na Placu Niebiańskiego Spokoju w czerwcu 1989 r. zawieszono wzajemne relacje; nałożono również na ChRL szereg sankcji, w tym embargo na broń. Znormalizowanie stosunków bilateralnych nastappiło w 1992 roku; w czerwcu ruszył dialog na temat ochrony środowiska naturalnego. W 1994 roku ogłoszono początek nowego dialogu politycznego. W 1995 roku rozpoczęto realizację dwustronnego Dialogu na temat Praw Człowieka (EU-China Human Rights Dialogue) ${ }^{1}$.

\footnotetext{
${ }^{1}$ Zob. szerzej: EU-China Relations: Chronology, China, European Union - EEAS (European External Action Service), http://eeas.europa.eu/china/docs/chronology_2010_en.pdf, 25 I 2011.
} 
W 1998 roku wprowadzono instytucje regularnych spotkań na najwyższym szczeblu; pierwszy szczyt UE-ChRL miał miejsce 2 kwietnia w Londynie, a ostatni - 13. w Brukseli 6 października 2010 roku. 22 grudnia 1998 roku podpisano porozumienie w sprawie współpracy naukowej i technologicznej. 15 maja 2001 roku Komisja Europejska opublikowała Strategię UE w stosunku do Chin. W 2003 roku dialog polityczny między UE a ChRL uzyskał rangę kompleksowego partnerstwa strategicznego. 13 października 2003 roku Chiny opublikowały białą księgę w sprawie kontaktów z Unią - po raz pierwszy w historii przyjęto Białą księgę w odniesieniu do kontaktów z partnerem zagranicznym. Podczas 8. szczytu unijno-chińskiego w 2005 roku ustanowiono Partnerstwo w sprawie Zmian Klimatycznych (Partnership on Climate Change). W grudniu natomiast zainaugurowano w Londynie Unijno-Chiński Dialog Strategiczny (EU-China Strategic Dialogue) ${ }^{2}$.

24 października 2006 roku Komisja przyjęła komunikat „UE-Chiny: bliższe partnerstwo, większa odpowiedzialność” (EU-China: Closer partners, growing responsibilities). Uwzględniając fakt, że Państwo Środka stało się ponownie światową potęgą gospodarczą i polityczną w dokumencie tym wskazano na podstawy wzajemnych relacji Unia-Chiny, którymi pozostają zaangażowanie i partnerstwo. Bliższe partnerstwo strategiczne oznacza wzrost wzajemnych oczekiwań i zobowiązań, ale także odpowiedzialności obu stron. Za priorytetowe uznano wsparcie dla reform w ChRL w kierunku pluralizmu i otwartego społeczeństwa; zrównoważony rozwój, w tym współpracę w zakresie zmian klimatycznych, energii i rozwiązywania problemów światowej gospodarki; zacieśnianie współpracy bilateralnej, zwłaszcza dotyczącej nauki i techniki, a także migracji; działania mające na celu stabilizację bezpieczeństwa międzynarodowego w Azji Wschodniej oraz w wymiarze globalnym, ze szczególnym uwzględnieniem zakazu proliferacji broni jądrowej ${ }^{3}$.

W styczniu 2007 roku rozpoczęły się negocjacje w sprawie nowej umowy unijno-chińskiej o partnerstwie i współpracy (EU-China Partnership and Cooperation Agreement - PCA), która w pełni ma odzwierciedlać kompleksowość strategicznego partnerstwa unijno-chińskiego. 25 kwietnia zapoczątkowano natomiast w Pekinie pierwszy Unijno-Chiński Dialog Wysokiego Szczebla Gospodarczy i Handlowy (EU-China High Level Economic and Trade Dialogue - HED) $)^{4}$.

Rok 2010 przyniósł intensyfikację instytucjonalnego wymiaru strategicznego partnerstwa unijno-chińskiego. W dniach 26 kwietnia-2 maja miała miejsce wizyta przewodniczącego Komisji Europejskiej José Manuela Barroso oraz Wysokiego przedstawiciela Unii do spraw zagranicznych i polityki bezpieczeństwa Catherine Ashton w Pekinie i Szanghaju. 6 maja uroczyście obchodzono 35. rocznicę ustanowienia stosunków dyplomatycznych między jednoczącą się Europą a Państwem Środka. W czasie wizyty w Chinach w dniach 30 sierpnia-4 września C. Ashton miało miejsce inauguracyjne spotkanie Wysokiego Szczebla Dialogu Strategicznego i Polityki Zagranicznej (High Level Strategic Dialogue and Foreign Ministerial) ${ }^{5}$.

Okazją do wzmocnienia wzajemnej współpracy był 13. szczyt unijno-chiński z udziałem przewodniczącego Rady Europejskiej Hermana van Rompuy, przewodniczącego Komisji

\footnotetext{
2 Ibidem.

${ }^{3}$ Zob. szerzej: Komunikat Komisji do Rady i Parlamentu Europejskiego-UE-Chiny: bliższe partnerstwo, większa odpowiedzialność, COM (2006), 632 wersja ostateczna, http://eur-lex.europa.eu/LexUriServ/LexUriServ.do?uri= COM:2006:0631:FIN:PL:HTML.

${ }^{4}$ EU-China Relations: Chronology, op. cit.

${ }^{5}$ Zob. szerzej: EU High Representative/Commission Vice-President Catherine Ashton visits China for first „Partnership" Dialogue, http://europa.eu/rapid/pressReleasesAction.do?reference=IP/10/1077\&format=HTML\&aged= $0 \&$ language $=$ en $\&$ guilanguage $=$ en, 25 I 2011.
} 
J. M. Barroso oraz premiera ChRL Wena Jiabao. Głównymi jego tematami były problemy globalne, w tym głównie zmiany klimatyczne i problematyka energetyczna, nierozprzestrzenianie broni jądrowej; sytuacja w regionie Azji i Pacyfiku, przede wszystkich w Afganistanie i Pakistanie; globalne zarządzanie; dialog polityczny, gospodarczy, wymiana handlowa oraz inwestycje; współpraca kulturalna oraz intensyfikacja kontaktów międzyludzkich ${ }^{6}$. Jeśli chodzi o te ostatnie przy okazji 13. szczytu 6-7 października 2010 roku odbyło się pierwsze europejsko-chińskie Wysokiego Szczebla Forum Kultury (High Level Cultural Forum). Na 13. spotkaniu na szczycie zapadła także decyzja o ustanowieniu roku 2011 Europejsko-Chińskim Rokiem Młodzieży ${ }^{7}$. Z kolei rok 2012 ma być ogłoszony Chińsko-Europejskim Rokiem Dialogu Międzykulturowego.

W rezultacie przedmiotowego rozszerzania wymiaru unijno-chińskiego partnerstwa strategicznego w drugiej połowie pierwszej dekady XXI wieku zakres wzajemnej współpracy znacznie się pogłębił. Z 17 obszarów wspólnego zainteresowania w 2004 roku obecnie obejmuje on ponad 50 różnych dziedzin ${ }^{8}$.

Na przestrzeni ostatnich lat dodatkowy kontekst relacji unijno-chińskich tworzy płaszczyzna dialogu z azjatyckimi ugrupowaniami regionalnymi, wśród których szczególne miejsce zajmuje nieformalna platforma wymiany zdań ASEM (Asia-Europe Meeting). Spotkania w ramach tej formuły zostały zainicjowane w roku 1996 podczas szczytu w Bangkoku. Jej podstawę stanowił dokument programowy pt. Ramowa Współpraca Azjatycko-Europejska (Asia-Europe Cooperation Framework - AECF), przyjęty w czasie szczytu ASEM w Londynie w 1998 roku. Cele procesu ASEM uaktualniono w nowej wersji dokumentu, którą przyjęto w 2000 roku (AECF 2000). W szczególności położono w nim nacisk na zobowiązania państw azjatyckich w zakresie rządów prawa i przestrzegania praw człowieka. Nie będąc substytutem relacji bilateralnych ASEM ma pełnić rolę komplementarną wobec nich. Obecnie skupia 45 uczestników - obok 27 państw unijnych, Komisji Europejskiej oraz ChRL, 10 członków Stowarzyszenia Narodów Azji Południowo-Wschodniej (Association of South-East Asian Nations - ASEAN) i Sekretariat tej organizacji, a także Japonię, Republikę Korei, Mongolię, Indie i Pakistan?.

Kwestia relacji UE-ChRL pojawia się także w kontaktach partnerów z innymi uczestnikami międzynarodowej współpracy politycznej i gospodarczej, w tym w szczególności w stosunkach transatlantyckich ${ }^{10}$, czego dobitnym przykładem jest problem zniesienia embarga na sprzedaż broni do Chin.

\section{Relacje gospodarcze}

Wzrastająca potęga ChRL, zarówno gospodarcza, jak i polityczna, a także fakt, iż gospodarka tego państwa jest obecnie drugą narodową gospodarką globu, natomiast Państwo Środ-

\footnotetext{
${ }^{6}$ Zob. szerzej: $13^{\text {th }}$ Summit - Brussels - 6 October 2010, China, European Union - EEAS (European External Action Service), http://eeas.europa.eu/china/summits_en.htm, 25 I 2011.

${ }^{7}$ Ibidem.

${ }^{8}$ Zob. szerzej: Sectoral dialogues, China, European Union - EEAS (European External Action Service), http://eeas.europa.eu/china/docs/sectoraldialogues_en.pdf, 25 I 2011.

${ }^{9}$ Zob. szerzej: Asia-Europe Meeting, http://www.aseminfoboard.org/, 30 I 2011.

${ }^{10}$ Zob. szerzej np.: Wystapienie Pana Ministra Radosława Sikorskiego na konferencji ,, Unia Europejska-Stany Zjednoczone - Chiny. Jak zbudować transatlantyckie zrozumienie w relacjach z rosnaca potegq azjatyckq", Warszawa, 11 stycznia 2008 r., Ministerstwo Spraw Zagranicznych Rzeczypospolitej Polskiej, http://www.mfa.gov.pl/files/WYSTAPIENIA/chinyPL.pdf, 30 I 2011.
} 
ka największym światowym eksporterem stanowią najważniejsze wyzwanie dla polityki handlowej UE. Zmierza ona do wspierania reform ekonomicznych i otwierania rynku chińskiego na świat, czego wyrazem było poparcie akcesji Chin do Światowej Organizacji Hanlu (World Trade Organization - WTO), co nastąiło 11 grudnia 2001 roku.

Chiny odgrywają coraz większą rolę w relacjach gospodarczych Unii z resztą świata, a ich udział w unijnym handlu wciąż rośnie. W latach 1978-2000 handel między EWG/UE a ChRL wzrósł ponad trzydziestokrotnie; natomiast biorąc pod uwagę okres 1978-2005 aż sześćdziesiątkrotnie (sic!). Od 1999 do końca 2009 roku wzajemne obroty handlowe wzrosły ponad czterokrotnie (tylko w latach 2003-2007 uległy podwojeniu). Państwo Środka awansowało na pierwszego najważniejszego azjatyckiego partnera gospodarczego Unii. W 2009 roku zajmowało drugie miejsce ustępując jedynie USA wśród najważniejszych partnerów gospodarczych jednoczącej się Europy. Przypadało na nie blisko 13\% zewnętrznych obrotów handlowych Unii o wartości ponad 296 mld euro (zob. tab. 1).

Najważniejsi partnerzy handlowi UE - lata 2007 i 2009

Tabela 1

\begin{tabular}{||c|l|c|r|l|r|c||}
\hline \multirow{2}{*}{ L.p. } & \multicolumn{3}{|c|}{$\mathbf{2 0 0 7}$} & \multicolumn{3}{c||}{$\mathbf{2 0 0 9}$} \\
\cline { 2 - 7 } & \multicolumn{1}{|c|}{ państwo } & mld euro & $\mathbf{\%}$ & państwo & mld euro & \% \\
\hline & Swiat & 2665,926 & 100,0 & Swiat & 2293,517 & 100,0 \\
\hline 1 & USA & 442,567 & 16,6 & USA & 364,002 & 15,9 \\
\hline 2 & Chiny & 303,273 & 11,4 & Chiny & 296,382 & 12,9 \\
\hline 3 & Rosja & 232,980 & 8,7 & Rosja & 180,761 & 7,9 \\
\hline 4 & Szwajcaria & 169,487 & 6,4 & Szwajcaria & 162,045 & 7,1 \\
\hline 5 & Japonia & 121,861 & 4,6 & Norwegia & 106,167 & 4,6 \\
\hline \hline
\end{tabular}

Źródło: Oprac. na podstawie: External Trade, Eurostat Home Page, http://epp.eurostat.ec.europa.eu/portal/page?_pageid=0,1136217,0_45571464\&_dad=portal\&_schema=PORTA, 20 XII 2008; EU and the World, External Trade, European Commission, http://ec.europa.eu/trade/issues/bilateral/data.htm, 20 XII 2008; EU Trade with Main Partners (2009), European Commission: Trade: China (Bilateral relations), http://trade.ec.europa.eu/doclib/docs/2006/september/tradoc_113366.pdf, 21 I 2011.

W ostatnich latach Chiny awansowały na pozycję trzeciego najważniejszego partnera eksportowego Unii, wyprzedzając w 2009 roku Federację Rosyjską i sytuując się tuż za Szwajcarią. W 2009 roku eksport unijny na rynek chiński stanowił 7,5\% całości sprzedaży zewnętrznej (tab. 2).

Tabela 2

Najważniejsi partnerzy eksportowi UE - lata 2007 i 2009

\begin{tabular}{||c|l|r|r|l|r|r||}
\hline \multirow{2}{*}{ L.p. } & \multicolumn{3}{|c|}{$\mathbf{2 0 0 7}$} & \multicolumn{3}{c||}{$\mathbf{2 0 0 9}$} \\
\cline { 2 - 7 } & \multicolumn{1}{|c|}{ państwo } & mld euro & $\mathbf{\%}$ & państwo & mld euro & \% \\
\hline & Swiat & 1239,919 & 100,0 & Swiat & 1094,229 & 100,0 \\
\hline 1 & USA & 261,463 & 21,1 & USA & 204,468 & 18,7 \\
\hline 2 & Szwajcaria & 92,787 & 7,5 & Szwajcaria & 88,292 & 8,1 \\
\hline 3 & Rosja & 89,100 & 7,2 & Chiny & 81,633 & 7,5 \\
\hline 4 & Chiny & 71,757 & 5,8 & Rosja & 65,481 & 6,0 \\
\hline 5 & Turcja & 52,641 & 4,2 & Turcja & 43,780 & 4,0 \\
\hline
\end{tabular}

Źródło: Oprac. na podstawie: External Trade, Eurostat Home Page, http://epp.eurostat.ec.europa.eu/portal/page?_pageid=0,1136217,0_45571464\&_dad=portal\&_schema=PORTA, 20 XII 2008; EU and the World, External Trade, European Commission, http://ec.europa.eu/trade/issues/bilateral/data.htm, 20 XII 2008; EU Trade with Main Partners (2009), European Commission: Trade: China (Bilateral relations), http://trade.ec.europa.eu/doclib/docs/2006/september/tradoc_113366.pdf, 21 I 2011. 
Od 2006 roku, kiedy to Chiny stały się najważniejszym źródłem unijnego importu, wyprzedzając Stany Zjednoczone, niezagrożona pozostaje ich pozycja jako głównego partnera importowego UE. Ponadto ciągle się ona umacnia - w 2009 roku import z Chin stanowił już blisko $18 \%$ całości unijnego importu (zob. szerzej tab. 3 ).

Tabela 3

Najważniejsi partnerzy importowi UE - lata 2007 i 2009

\begin{tabular}{||c|l|c|r|l|r|c||}
\hline \multirow{2}{*}{ L.p. } & \multicolumn{3}{|c|}{$\mathbf{2 0 0 7}$} & \multicolumn{3}{c||}{$\mathbf{2 0 0 9}$} \\
\cline { 2 - 7 } & \multicolumn{1}{|c|}{ państwo } & mld euro & $\mathbf{\%}$ & państwo & mld euro & \% \\
\hline & Świat & 1426,008 & 100,0 & Świat & 1199,288 & 100,0 \\
\hline 1 & ChRL & 231,516 & 16,2 & ChRL & 214,793 & 17,9 \\
\hline 2 & USA & 181,104 & 12,7 & USA & 159,534 & 13,3 \\
\hline 3 & Rosja & 143,880 & 10,1 & Rosja & 115,280 & 9,6 \\
\hline 4 & Japonia & 78,104 & 5,5 & Szwajcaria & 73,753 & 6,1 \\
\hline 5 & Norwegia & 76,841 & 5,4 & Norwegia & 68,651 & 5,7 \\
\hline
\end{tabular}

Źródlo: Oprac. na podstawie: External Trade, Eurostat Home Page, http://epp.eurostat.ec.europa.eu/portal/page?_pageid=0,1136217,0_45571464\&_dad=portal\&_schema=PORTA, 20 XII 2008; EU and the World, External Trade, European Commission, http://ec.europa.eu/trade/issues/bilateral/data.htm, 20 XII 2008; EU Trade with Main Partners (2009), European Commission: Trade: China (Bilateral relations), http://trade.ec.europa.eu/doclib/docs/2006/september/tradoc_113366.pdf, 21 I 2011.

Dla ChRL Unia Europejska jest najważniejszym na świecie partnerem gospodarczym i wyprzedza na tej płaszczyźnie USA oraz państwa azjatyckie: Hongkong, Japonię i Koreę Południową. Przypadało na nią w 2009 roku 17,3\% całości obrotów handlowych Państwa Środka o wartości 270,433 mld euro ${ }^{11}$, w tym $13,4 \%$ importu oraz 20,4\% eksportu (zob. szerzej tab. 4).

Tabela 4

Najważniejsi partnerzy handlowi ChRL w roku 2009

\begin{tabular}{|c|c|c|c|c|c|c|}
\hline \multirow{2}{*}{ L.p. } & \multicolumn{3}{|c|}{2007} & \multicolumn{3}{|c|}{2009} \\
\hline & państwo & mld euro & $\%$ & państwo & mld euro & $\%$ \\
\hline & Świat & 880,922 & 100,0 & Świat & 678,321 & 100,0 \\
\hline 1 & UE & 179,474 & 20,4 & UE & 90,959 & 13,4 \\
\hline 2 & USA & 179,044 & 20,3 & Japonia & 89,568 & 13,2 \\
\hline 3 & Hongkong & 108,307 & 12,3 & Hongkong & 70,810 & 10,4 \\
\hline 4 & Japonia & 74,612 & 8,5 & Korea Południowa & 66,273 & 9,8 \\
\hline 5 & Korea Południowa & 40,891 & 4,6 & USA & 55,946 & 8,2 \\
\hline
\end{tabular}

Źródło: EU Trade with Main Partners (2009), European Commission: Trade: China (Bilateral relations), http://trade.ec.europa.eu/doclib/docs/2006/september/tradoc_113366.pdf, 21 I 2011.

W 2007 roku całość (włączając usługi) eksportu unijnego na rynek chiński osiągnęła wartość 89,9 mld euro; import wyniósł 246,7 mld euro. Na skutek pogłębiającego się kryzysu gospodarczego dynamika wzajemnych obrotów handlowych uległa w kolejnych latach nie-

${ }^{11}$ China's Trade with Main Partners (2009), European Commission: Trade: China (Bilateral relations), http://trade.ec.europa.eu/doclib/docs/2006/september/tradoc_113366.pdf, 21 I 2011. 
znacznemu spowolnieniu. W 2009 roku eksport unijny do ChRL kształtował się na poziomie 99,6 mld euro, podczas gdy import wyniósł 227,8 mld euro (zob. tab. 5 i 6).

W latach osiemdziesiątych XX wieku Wspólnoty Europejskie miały dodatnie saldo w handlu z Chinami. Dynamiczny wzrost importu z Chin od początku lat dziewięćdziesiątych doprowadził jednak do powstania dużego deficytu handlowego, a w konsekwencji do ujemnego salda na europejskim rachunku obrotów bieżących. W 2009 roku deficyt handlowy na skutek osłabienia dynamiki importu uległ zmniejszeniu o 36,4 mld euro w porównaniu z rokiem poprzednim, do poziomu nieco ponad 133 mld euro (tab. 5). Dodatnim bilansem handlowym Unia może się natomiast pochwalić w handlu usługami, których udział we wzajemnych obrotach handlowych systematycznie rośnie (zob. tab. 6).

Tabela 5

Obroty towarowe UE z ChRL

\begin{tabular}{|l|c|c|c|c|c||}
\hline & $\mathbf{2 0 0 5}$ & $\mathbf{2 0 0 6}$ & $\mathbf{2 0 0 7}$ & $\mathbf{2 0 0 8}$ & $\mathbf{2 0 0 9}$ \\
\hline Import w mld euro & 160,3 & 194,9 & 232,7 & 247,9 & 214,1 \\
\hline \% całości importu UE & 13,6 & 14,4 & 16,2 & 15,8 & 17,8 \\
\hline Eksport w mld euro & 51,8 & 63,8 & 71,9 & 78,4 & 82,4 \\
\hline \% całości eksportu UE & 4,9 & 5,5 & 5,8 & 6,0 & 7,5 \\
\hline Saldo w mld euro & $-108,5$ & $-131,1$ & $-160,7$ & $-169,5$ & $-131,7$ \\
\hline
\end{tabular}

Źródło: Oprac. własne na podstawie: 2A: Main EU trading partners; $2 B / C$ : Yearly/Monthly trends in EU trade by partner, „External and intra-European Union Trade (Monthly statistics)” 2010, nr 12, s. 42-43, 49.

Tabela 6

Obroty usługami UE z ChRL (z wyjątkiem „usług rządowych”)

\begin{tabular}{||l|r|r|r||}
\hline & $\mathbf{2 0 0 7}$ & $\mathbf{2 0 0 8}$ & $\mathbf{2 0 0 9}$ \\
\hline Import w mld euro & 14,0 & 15,0 & 13,1 \\
\hline \% całości importu UE & 3,4 & 3,4 & 3,2 \\
\hline Eksport w mld euro & 18,0 & 19,9 & 18,0 \\
\hline \% całości eksportu UE & 3,6 & 3,9 & 3,8 \\
\hline Saldo w mld euro & 4,0 & 4,9 & 5,0 \\
\hline
\end{tabular}

Źródlo: Oprac. własne na podstawie: China, Trade in Commercial Services (Services Excluding ,, Government Services”), European Commission: Trade: China (Bilateral relations), http://trade.ec.europa.eu/doclib/docs/2006/september/tradoc_113366.pdf, 21 I 2011.

Wśród państw członkowskich Unii największymi partnerami eksportowymi Chin w 2009 roku były: Niemcy (44,2\% eksportu unijnego do Państwa Środka o wartości 36,4 mld euro), Francja (9,6\% i 7,9 mld euro), Włochy (8\% i 6,6 mld euro), Wielka Brytania (6,9\% i 5,7 mld euro) oraz Holandia (5,7\% i 4,7 mld euro). Największy udział w imporcie z ChRL do UE przypadł także na Niemcy (21,5\% udziału w ogólnym imporcie z Chin do Unii i wartości 46 mld euro), Holandię (17,2\% i 36,9 mld euro), Wielką Brytanię (14,3\% i 30,6 mld euro), Włochy (9\% i 19,3 mld euro) oraz Francję (8,3\% i 17,8 mld euro). Wszystkie te państwa odnotowały deficyt z kontaktach handlowych. Największy zaobserwowano w przypadku Holandii (32,2 mld euro), dalej w Wielkiej Brytanii (24,8 mld euro), Włoszech (12,6 mld euro), Niemczech (9,5 mld euro), Francji $(9,9 \text { mld euro })^{12}$.

\footnotetext{
${ }^{12}$ External and intra-European Union trade. Data 2004-09, Luxembourg 2011, s. 54, 64, 66, 80, 98.
} 
We wzajemnych obrotach dominuje przepływ towarowy. Największy udział w unijnym imporcie z Chin w 2009 roku miały towary przemysłowe, w tym na pierwszym miejscu komputery i sprzęt biurowy (14,5\% całości importu), telefony komórkowe $(13,6 \%)$, odzież $(12,4 \%)$, urządzenia elektryczne $(7,8 \%)$, artykuły użytku osobistego i domowego oraz półprodukty (po 7,6\%). Wśród towarów eksportowanych do Państwa Środka dominowały: maszyny $(34,3 \%)$, urządzenia transportowe $(17,5 \%)$ i chemikalia $(11,7 \%)^{13}$ - zob. szerzej tabela 7 .

Tabela 7

Struktura towarowa importu do oraz eksportu UE z Chin (2009)

\begin{tabular}{|c|c|c|c|}
\hline Grupy towarów & \begin{tabular}{|c|} 
Udzial \\
w imporcie
\end{tabular} & Grupy towarów & \begin{tabular}{|c|} 
Udzial \\
w eksporcie \\
\end{tabular} \\
\hline $\begin{array}{l}\text { SITC } 7 \text { - Maszyny i urządzenia transpor- } \\
\text { towe }\end{array}$ & 47,5 & $\begin{array}{l}\text { SITC } 7 \text { - Maszyny i urządzenia transpor- } \\
\text { towe }\end{array}$ & 58,1 \\
\hline SITC 8 - Różne wyroby przemysłowe & 33,9 & SITC 5-Chemikalia i produkty pokrewne & 11,7 \\
\hline $\begin{array}{l}\text { SITC } 6 \text { - Towary przemysłowe sklasyfi- } \\
\text { kowane wg surowca }\end{array}$ & 11,2 & $\begin{array}{l}\text { SITC } 6 \text { - Towary przemysłowe sklasyfi- } \\
\text { kowane wg surowca }\end{array}$ & 11,1 \\
\hline SITC 5-Chemikalia i produkty pokrewne & 3,2 & $\begin{array}{l}\text { SITC } 2 \text { - Surowe, niejadalne towary z wyj. } \\
\text { paliw }\end{array}$ & 7,0 \\
\hline SITC 0 - Żywność i żywe zwierzęta & 1,5 & SITC 8 - Różne wyroby przemysłowe & 6,5 \\
\hline $\begin{array}{l}\text { SITC 2 - Surowe, niejadalne towary z wyj. } \\
\text { paliw }\end{array}$ & 0,9 & SITC 9 - Inne towary & 1,2 \\
\hline SITC 9 - Inne towary & 0,4 & SITC 0 - Żywność i żywe zwierzęta & 1,2 \\
\hline $\begin{array}{l}\text { SITC } 3 \text { - Paliwa mineralne, smary i mate- } \\
\text { riały pochodne }\end{array}$ & 0,1 & SITC 1 - Napoje i tytoń & 0,6 \\
\hline SITC 1 - Napoje i tytoń & 0,0 & $\begin{array}{l}\text { SITC } 3 \text { - Paliwa mineralne, smary i mate- } \\
\text { riały pochodne }\end{array}$ & 0,2 \\
\hline $\begin{array}{l}\text { SITC } 4 \text {-Oleje zwierzęce i roślinne, thusz- } \\
\text { cze i woski }\end{array}$ & 0,0 & $\begin{array}{l}\text { SITC } 4 \text {-Oleje zwierzęce i roślinne, thusz- } \\
\text { cze i woski }\end{array}$ & 0,1 \\
\hline
\end{tabular}

Źródło: Oprac. własne na podstawie: European Union, Trade with the World and China, by SITC section (2009), European Commission: Trade: China (Bilateral relations), http://trade.ec.europa.eu/doclib/docs/2006/september/tradoc_113366.pdf, 21 I 2011.

Rosnący wolumen unijno-chińskiej wymiany handlowej wywiera znaczący wpływ na obu partnerów. Po stronie Unii występuje tzw. efekt cenowy, wiążący się z wpływem, jaki wywiera import z Chin na ceny dóbr konsumpcyjnych w Europie. Napływ tanich towarów chińskich działa antyinflacyjnie. Obniżenie poziomu inflacji pozwala natomiast utrzymać stopy procentowe na niższym poziomie, co stymuluje wzrost gospodarczy, z kolei niższe ceny zwiększają siłę nabywczą konsumentów (ale także powodują wyrównywanie się ceny siły roboczej). Wśród korzyści po stronie chińskiej to oczywiście zyski płynące z eksportu (terms of trade zawsze korzystniejsze jest dla eksporterów). Istotna jest także struktura importu chińskiego z UE (zaawansowane produkty o wysokiej wartości dodanej), dzięki której ChRL uzyskuje dostęp do najnowszych technologii i wiedzy ${ }^{14}$.

${ }^{13}$ Rank of China in European Union Trade (2009), European Commission: Trade: China (Bilateral relations), http://trade.ec.europa.eu/doclib/docs/2006/september/tradoc_113366.pdf, 21 I 2011.

${ }^{14}$ T. Kamiński, Problemy gospodarcze w relacjach Unii Europejskiej z Chinami, w: „Powrót Smoka”. Marsz ku pozycji globalnego mocarstwa, red. J. Marszałek-Kawa, Toruń 2008, s. 45-47. 
Unia Europejska jest obecnie drugim po Hongkongu źródłem bezpośrednich inwestycji zagranicznych w Chinach. W latach 2006-2009 zainwestowano prawie 23 mld euro. W 2009 roku europejskie przedsiębiorstwa zainwestowały w Chinach 5,3 mld euro, podczas gdy w odwrotnym kierunku napłynęło jedynie 300 mln euro. Jednak wartość chińskich inwestycji w UE systematycznie rośnie, mimo znacznego osłabienia ich dynamiki w 2008 roku (zob. szerzej tab. 7). W ostatnich latach Chiny poczyniły w Unii Europejskiej wiele inwestycji, takich jak zakup sektora samochodów osobowych Volvo w Szwecji czy koncernu Forda przez chiński koncern Geely ${ }^{15}$. Szczególne kontrowersje wzbudzają przy tym przejęcia przez Chiny europejskich firm z dziedziny zaawansowanych technologii.

Tabela 8

Bezpośrednie inwestycje zagraniczne

\begin{tabular}{||l|l|c|c|c|c||}
\hline \multicolumn{2}{|c|}{} & $\mathbf{2 0 0 6}$ & $\mathbf{2 0 0 7}$ & $\mathbf{2 0 0 8}$ & $\mathbf{2 0 0 9}$ \\
\hline \multirow{2}{*}{ W UE w mld euro } & w ciągu roku & - & 0,8 & $-0,1$ & 0,3 \\
\cline { 2 - 6 } & skumulowana wartość & 3,6 & 4,7 & 13,9 & - \\
\hline \multirow{2}{*}{ W ChRL w mld euro } & w ciagu roku & - & 6,6 & 4,7 & 5,3 \\
\cline { 2 - 6 } & skumulowana wartość & 32,6 & 40,1 & 47,3 & - \\
\hline \multirow{2}{*}{ Saldo w mld euro } & w ciągu roku & - & 5,8 & 4,8 & 5,0 \\
\cline { 2 - 6 } & skumulowana wartość & 29,0 & 35,4 & 33,4 & - \\
\hline
\end{tabular}

Źródło: Oprac. własne na podstawie: China, Foreign Direct Investment, European Commission: Trade: China (Bilateral relations), http://trade.ec.europa.eu/doclib/docs/2006/september/tradoc_113366.pdf, 21 I 2011.

Nowym aspektem inwestycji chińskich w Unii jest zakup przez rząd w Pekinie obligacji skarbowych państw europejskich najbardziej zagrożonych skutkami kryzysu finansowego. Latem 2010 roku zakupiono hiszpańskie obligacje rządowe na kwotę $400 \mathrm{mln}$ euro. Pod koniec grudnia 2010 roku pojawiły się spekulacje na temat zakupu przez rząd chiński portugalskich obligacji skarbowych, a także greckich ${ }^{16}$. Chińska oferta otwarta jest także do innych państw unijnych szczególnie dotkniętych kryzysem. W rezultacie Państwo Środka stać się może bankierem Europy (pełniąc już taką rolę w odniesieniu do gospodarki amerykańskiej) i wpływać znacząco na kurs euro.

\section{Główne problemy gospodarcze we wzajemnych stosunkach}

W relacjach gospodarczych między UE a ChRL do najważniejszych kwestii rozbieżności dochodzi na płaszczyźnie libaralizacji wzajemnych obrotów handlowych i otwartości rynków (głównie chińskiego). Bardzo ważnym problemem jest przestrzeganie przez Chiny praw własności intelektualnej, a także ciagle niskie standardy produkcyjne.

Zobowiązując się do otwartych stosunków handlowych z Chinami, Unia kładzie nacisk na przestrzeganie przez rząd w Pekinie zobowiązań wynikających z kolejnych negocjacji w ra-

\footnotetext{
${ }^{15}$ Chińska firma Geely kupiła markę Volvo za 1,8 mld dolarów, Forsal.pl, http://forsal.pl/artykuly/409535,chinska_firma_geely_kupila_marke_volvo_za_1_8_mld_dolarow.html, 21 I 2011.

${ }^{16}$ Chiny chcq być bankierem Europy, Forsal.pl, http://forsal.pl/artykuly/473513,chiny_chca_byc_bankierem_europy.html, 21 I 2011; Chiny kupujq_wptywy na świecie, Forsal.pl, http://forsal.pl/artykuly/473858,chiny_kupuja_wplywy_na_swiecie.html, 21 I 2011.
} 
mach najpierw Układu Ogólnego w sprawie Taryf Celnych i Handlu (General Agreement on Tariffs and Trade - GATT), a od 1995 roku Światowej Organizacji Handlu. Po przystapieniu ChRL do WTO obniżono taryfy celne oraz ograniczono bariery pozataryfowe. Poczyniono znaczne postępy w liberalizacji gospodarki, a unijne przedsiębiorstwa uzyskały lepszy dostęp do chińskiego rynku. Bez wątpienia także strategiczne partnerstwo UE z ChRL sprzyja tworzeniu klimatu dla dynamicznego rozwoju inwestycji. Swoboda dostępu do chińskiego rynku w dużej mierze zależy jednak od preferencji politycznych rządu w Pekinie, oceny spodziewanych korzyści gospodarczych, w tym uzyskania zróżnicowanych źródeł dostaw nowoczesnych technologii. Wejście na chiński rynek jest ciagle trudne i kosztowne także ze względu na konkurencję firm z całego świata oraz odległość. Niejasny jest system prawny, czasochłonne procedury certyfikacyjne i standaryzacyjne. Stosowane są różnego typu postępowania ochronne, a rozbudowany system licencji i kontyngentów, zmieniające się zakazy importu szeregu artykułów rolno-spożywczych to kolejne pozataryfowe bariery w dostępie do rynku. Europejskie przedsiębiorstwa ciaggle napotykają liczne przeszkody związane z wysokim poziomem biurokratyzacji i skomplikowanymi procedurami, mimo podpisanej przez Chiny w 2008 roku umowy o otwartości rynku. Znacznie utrudniony jest dostęp do rynku zamówień publicznych. Na rynku chińskim ciagle istnieją ograniczenia działalności firm zagranicznych m.in. w przemyśle stalowym, samochodowym, petrochemicznym, tekstylnym i odzieżowym. W szczególności problem ten dotyczy sektora bankowego i ubezpieczeniowego, budownictwa, usług pocztowych oraz telekomunikacyjnych. Przykładowo z 22 tys. licencji telekomunikacyjnych, których udzielono od 2001 roku tylko 14 otrzymały zagraniczne firmy. Zagraniczne kancelarie prawnicze nie mogą zatrudniać chińskich prawników, ani taż uzyskiwać chińskich kwalifikacji ${ }^{17}$.

Na przeszkodzie działalności unijnych przedsiębiorstw stoi także chińska polityka inwestycyjna polegająca na faworyzowaniu miejscowych przedsiębiorców przy wykorzystaniu zagranicznych kapitałów i technologii. Liczyć się trzeba z bardzo wysokimi kosztami akwizycji i reklamy. Problem stanowi bariera językowa i obyczajowa. Bardzo ważny w prowadzeniu interesów w Chinach jest system personalnych powiązań i znajomości i układów - guanxi. Drugim elementem chińskiej „kultury biznesowej” jest mianzi, czyli reputacja, wiążąca się z szacunkiem w grupie i społeczeństwie ${ }^{18}$. Potencjalny eksporter/inwestor ma do czynienia z całkowicie różną od europejskiej kulturą, gustami i przyzwyczajeniami. Mimo to chiński rynek jest bardzo atrakcyjny ze względu na ogromną liczbę potencjalnych odbiorców oraz na coraz większą grupę osób zamożnych i bardzo zamożnych.

Istotnym problem we wzajemnych relacjach gospodarczych jest masowe łamanie w Chinach praw własności intelektualnej. Tylko w 2004 roku skopiowano w ChRL programy komputerowe, filmy i muzykę o wartości około 2,6 mld USD ${ }^{19}$. Podrabiane są także odzież i obuwie, przy czym są to podróbki coraz lepszej jakości. Według szacunków w 2007 roku europejscy przedsiębiorcy na skutek łamania praw własności stracili $20 \%$ swoich potencjalnych zysków. Blisko 54\% wszystkich podrobionych towarów zajętych na granicach Europy

\footnotetext{
${ }^{17}$ EU-China trade in facts and figures, European Commission: Trade: China (Bilateral relations), http://trade.ec.europa.eu/doclib/docs/2009/september/tradoc_144591.pdf, 28 I 2011.

${ }^{18}$ Zob. szerzej: J. Strzelecki, Chiny: strefa specjalnego znaczenia, Portal Innowacji, http://www.pi.gov.pl/PARP/chapter_86196.asp?soid=8DCE190A72EB4642A0CC941282A282DA, 28 I 2011.

${ }^{19}$ K. Hołdak, A. Konarzewska, Stosunki Unii Europejskiej z Chinami, „Bezpieczeństwo Narodowe” 2007, nr 5-6, s. 282.
} 
w 2008 roku pochodziło z Chin. Siedem na dziesięć europejskich firm działających w Chinach jest ofiarą naruszeń praw autorskich i patentowych ${ }^{20}$.

Wpływ na wzajemne relacje handlowe ma także kwestia niskich standardów produkcyjnych w Chinach. W wymiarze środowiskowym problem ten wiąże się z nieprzestrzeganiem norm w zakresie ochrony środowiska w rezultacie niedostatecznych inwestycji w przyjazne mu technologie. Zbytnie zaostrzenie przepisów zdaniem władz chińskich wiązałoby się ze zwiększeniem kosztów produkcji i mogłoby spowolnić wzrost gospodarczy. Głównym problemem socjalnym leżącym u podstaw niskich standardów produkcyjnych w Państwie Środka jest natomiast tzw. dumping socjalny, wynikający z nie wdrożenia przez rząd w Pekinie czterech podstawowych konwencji Międzynarodowej Organizacji Pracy (MOP; International Labour Organization - ILO) ${ }^{21}$.

Najważniejszym skutkiem niskich standardów produkcyjnych jest jednak kwestia bezpieczeństwa chińskich produktów sprzedawanych na unijnym rynku. Według danych Wspólnotowego Systemu Szybkiej Informacji (European Rapid Alert System - RAPEX) ${ }^{22}$ w 2006 roku na tysiąc produktów wycofanych ze sprzedaży w Unii Europejskiej z powodu uznania za niebezpieczne ponad połowa pochodziła z Państwa Środka. W kolejnych latach odsetek ten wzrastał - do 60\% w 2009 roku (1013 powiadomień). Najwyższy udział w produktach niebezpiecznych mają zabawki dziecięce i odzież, następnie pojazdy oraz produkty elektrotechniczne. W 2009 roku aż 80\% zabawek mechanicznych uznanych za niebezpieczne wyprodukowano w Chinach ${ }^{23}$. Rozpatrując te dane, należy jednak mieć na uwadze, że import z ChRL stanowi znaczną część ogólnego importu do UE (np. 80\% wszystkich zabawek), oraz że nadzór nad chińskimi produktami jest ściślejszy niż w wypadku wielu innych państw. W tym celu w 2004 roku podpisany został Protokół Ustaleń (Memorandum of Understanding - MoU) między Dyrekcją Generalną ds. Zdrowia i Ochrony Konsumentów (Directorate-General for Health and Consumers - DG SANCO) a jej chińskim odpowiednikiem - Administracją Ogólną do spraw Nadzoru Jakości, Inspekcji i Kwarantanny ChRL (Chinese General Administration for Quality Supervision, Inspection and Quarantine - AQSIQ). Na jego podstawie utworzony został system RAPEX-Chiny (RAPEX-CHINA), umożliwiający szybkie przesyłanie danych między Unią a Chinami w zakresie produktów konsumenckich uznanych za niebezpieczne ${ }^{24}$.

Współpraca jednoczącej się Europy z Państwem Środka w zakresie bezpieczeństwa produktów znacznie pogłębiona została w 2007 roku. Po wizycie w Chinach Komisarz ds. Ochrony Konsumenta Megleny Kunewy w czerwcu wdrożono nowy system kwartalnych sprawozdań na temat działań rządu w Pekinie w zakresie egzekwowania przepisów, które mają pomóc w wykrywaniu źródeł towarów niebezpiecznych notyfikowanych w ramach systemu RAPEX-Chiny, a następnie w podjęciu działań naprawczych ${ }^{25}$.

${ }^{20}$ EU-China trade in facts..., op. cit.

${ }^{21}$ T. Kamiński, op. cit., s. 55-56.

${ }^{22}$ Utworzony w 1984 roku system, działający na obszarze Jednolitego Rynku UE. Jego celem jest szybka wymiana informacji między Komisją Europejską a państwami członkowskimi na temat produktów nieżywnościowych mogących stanowić zagrożenie dla konsumentów, a także środków podjętych przez poszczególne państwa w kierunku wyeliminowanie zagrożenia przez ograniczenie lub zakaz wprowadzania danego produktu na rynek.

${ }^{23}$ Questions and answers on the Community rapid information system for dangerous products (RAPEX), MEMO/10/130, Brussels, 15 April 2010, http://europa.eu/rapid/pressReleasesAction.do?reference=MEMO/10/ 130\& format=HTML\&aged=0\&language=EN\&guiLanguage=en, 28 I 2011.

${ }^{24}$ Rapex-China System, China \& the EU, Delegation of the European Union to China, http://ec.europa.eu/delegations/china/eu_china/food_safety_and_consumer_protection/rapex_china_system/index_en.htm, 28 I 2011.

${ }^{25}$ Zob. szerzej: The 'RAPAX-CHINA' Apllication, http://ec.europa.eu/consumers/safety/int_coop/docs/20100929_analysis_14th_rapex_report.pdf, 28 I 2011. 
Instrumentem rozwiązywania problemów będących przedmiotem wspólnego zainteresowania w dziedzinie inwestycji, dostępu do rynków, ochrony praw własności intelektualnej i standardów produkcyjnych jest powołany w 2008 roku Unijno-Chiński Dialog Wysokiego Szczebla Gospodarczy i Handlowy. Będąc jednym z dialogów sektorowych zajmuje się on na szczeblu wicepremiera sprawami o strategicznym znaczeniu we wzajemnych stosunkach gospodarczych. Do tej pory odbyły się trzy spotkania w ramach tego mechanizmu. Po inauguracyjnym w Pekinie, kolejne miało miejsce w Brukseli 7 i 8 maja 2009 roku. Jego głównym tematem była poprawa możliwości funkcjonowania biznesu w czasie kryzysu. Uznano, że dalsza liberalizacja handlu i przepływu inwestycji są najważniejszymi katalizatorami ożywienia wzrostu gospodarczego ${ }^{26} .20-21$ grudnia 2010 roku odbyło się w Pekinie trzecie spotkanie w ramach HED, w czasie którego podjęto dyskusję nad takimi problemami jak m.in. kwestie ogólnej sytuacji makroekonomicznej w gospodarce światowej i wpływu obecnych trendów na gospodarki Unii oraz Chin; zagadnienia konkurencji, handlu oraz inwestycji; prawa własności intelektualnej; innowacje; współpraca celna ${ }^{27}$.

\section{Pomoc rozwojowa}

Mimo imponującego wzrostu gospodarczego oraz faktu, że w drugiej połowie pierwszej dekady XXI wieku gospodarka chińska stała się drugą po amerykańskiej gospodarką narodową globu, dystansując mocarstwa gospodarcze takie jak Japonia oraz Niemcy, współczesnych Chin nie można zaliczyć do państw wysokorozwiniętych. Ubóstwo, zwłaszcza na obszarach wiejskich jest zjawiskiem nagminnym - ocenia się, że około $11 \%$ populacji chińskiej żyje w skrajnym ubóstwie. Imponujący produkt krajowy brutto, który według szacunków w 2010 roku osiagnął wartość ponad 9,82 bln USD, zapewniając Państwu Środka drugą pozycję w rankingach światowych, wyniósł jedynie 7,4 tys. USD per capita (co sytuowało ChRL dopiero na 127. miejscu na świecie, m.in. za takimi państwami jak Albania czy Angola) ${ }^{28}$. Szczególnie istotnymi problemami są dysproporcje rozwojowe między poszczególnymi regionami Chin oraz kwestia reform społeczno-ustrojowych. Dlatego też ChRL jest jednym z państw, w odniesieniu do których Unia realizuje politykę rozwojową.

W 1980 roku Chiny zostały objęte Systemem Preferencji Generalnych (Generalized System of Preferences - GSP), a do 1990 roku stały się jednym z jego głównym beneficjentów. $\mathrm{W}$ rezultacie z systemu wycofywano towary importowane z Chin, które stały się na tyle konkurencyjne, aby móc skutecznie rywalizować z europejskimi na rynku unijnym. W ramach China Country Strategy Paper 2002-2006 na pomoc rozwojową dla Chin przeznaczono ponad 250 mln euro w ramach 40 projektów. Blisko połowa środków została skierowana na wsparcie reform społeczno-ekonomicznych, w tym procesu budowy systemu zabezpieczeń socjalnych, a następnie polityki zrównoważonego rozwoju. Beneficjentami pomocy były zarówno administracja publiczna, jak i organizacje pozarządowe ${ }^{29}$.

\footnotetext{
${ }^{26}$ Zob. szerzej: Second meeting of the EU-China High Level Economic and Trade Dialogue: 7 and 8 May 2009 in Brussels. Factsheet, http://trade.ec.europa.eu/doclib/docs/2009/may/tradoc_143111.pdf, 28 I 2011.

${ }^{27}$ Zob. szerzej: Third meeting of the EU-China High Level Economic and Trade Dialogue (HED) in Beijing, http://trade.ec.europa.eu/doclib/docs/2010/december/tradoc_147155.pdf, 28 I 2011.

${ }^{28}$ China, CIA - The World Factbook, https://www.cia.gov/library/publications/the-world-factbook/geos/ch.html, 30 I 2011.

${ }^{29}$ Zob. szerzej: Commission Working Document, Country Strategy Paper CHINA, http://www.eeas.europa.eu/ china/csp/02_06_en.pdf, 28 I 2011.
} 
W China Strategy Paper 2007-2013 środki na pomoc rozwojową dla Chin określono w przybliżeniu na kwotę $224 \mathrm{mln}$ euro. Redukcja funduszy jest efektem dostrzeżenia przez Unię pozytywnych skutków rozwoju gospodarczego Chin, w efekcie którego są one w coraz większym stopniu zdolne do samodzielnego finansowania reform, a pomoc unijna nie jest już im niezbędna. Pomoc finansowa obejmuje program reform na obszarach objętych unijno-chińskim dialogiem sektorowym. Ma również na celu wsparcie Chin w rozwiązywaniu problemów globalnych, w tym związanych ze zmianami klimatycznymi, środowiskiem naturalnym oraz energią, a także rozwój zasobów ludzkich ${ }^{30}$.

\section{Dialog polityczny}

Biorąc pod uwagę rosnącą siłę gospodarczą i polityczną Chińskiej Republiki Ludowej, fakt jej stałego członkostwa w Radzie Bezpieczeństwa ONZ, a także coraz większą aktywność międzynarodową Państwa Środka i jego wpływ na szereg kwestii o zasięgu globalnym Unia Europejska zobowiązała się do umacniania dialogu politycznego z rządem w Pekinie. Unia zdaje sobie sprawę, że współpraca z Chinami, zarówno bilateralna, jak również na wielostronnych forach międzynarodowych ma kluczowe znaczenie dla obu partnerów, jak również infrastruktury międzynarodowego bezpieczeństwa i pokoju w skali globalnej.

Podstawą dialogu politycznego między UE a ChRL jest zbliżona wizja rzeczywistości międzynarodowej. Zarówno jednocząca się Europa, jak również Państwo Środka postrzegają współczesny system międzynarodowy w kategoriach wielobiegunowości, przywiązując dużą wagę do wielostronnej i wielopłaszczyznowej współpracy międzynarodowej zgodnie z poszanowaniem powszechnych zasad stosunków międzynarodowych oraz prawa międzynarodowego. Jednakże na tej płaszczyźnie uwidaczniają się także istotne rozbieżności między obydwoma podmiotami. W Unii dominuje podejście neoliberalne, wyrażające się głównie w randze przyznawanej organizacjom międzynarodowym jako uczestnikom stosunków międzynarodowych. Sztandarowym przykładem jest tutaj sama Unia Europejska - bezprecedensowy sukces procesów integracyjnych, zarówno w wymiarze wewnętrznym, jak również międzynarodowym. Z kolei propagowana przez rząd w Pekinie wizja współczesnego systemu międzynarodowego zdecydowanie bliższa jest paradygmatowi realistycznemu: postrzeganiu stosunków międzynarodowych w kategoriach relacji międzymocarstwowych w oparciu o zasadę równowagi sił $^{31}$.

Dialog polityczny zapoczątkowany 1994 roku miał na celu pogłębienie wzajemnych relacji o nowy wymiar współpracy. W czerwcu 2002 roku zdecydowano o aktualizacji jego ram na drodze wymiany listów, które stanowią podstawę prawną dla bieżących kwestii. Zakres dialogu politycznego UE-Chiny stopniowo rozszerzano od zagadnień związanych z problemami bezpieczeństwa w Azji, do globalnego ocieplenia oraz walki z nielegalną migracją i handlem ludźmi. W celu pogłębienia wymiaru współpracy politycznej zdecydowano o nadaniu jej rangi kompleksowego partnerstwa strategicznego oraz powołaniu nowych mechanizmów współdziałania w jego ramach: Dialogu na temat Praw Człowieka, Partnerstwa w spawie Zmian Klimatycznych, Dialogu Strategicznego i wreszcie Wysokiego Szczebla

${ }^{30}$ China Stategy Paper 2007-2013, Country Strategy Papers 2007-2013, European Union - EEAS (European External Action Service), http://eeas.europa.eu/china/csp/07_13_en.pdf, 27 I 2011.

${ }^{31}$ Por.: A. Kołodziejczyk, Chińskie wizje rzeczywistości międzynarodowej, w: Porzqdek międzynarodowy u progu XXI wieku, red. R. Kuźniar, Warszawa 2005, s. 335-356. 
Dialogu Strategicznego i Polityki Zagranicznej z udziałem Wysokiego przedstawiciela Unii do spraw zagranicznych i polityki bezpieczeństwa oraz jego odpowiednika w chińskiej Radzie Państwa.

Ramy instytucjonalne unijno-chińskiego dialogu politycznego przedstawiają się następująco:

- coroczne spotkania na szczycie na poziomie szefów państw lub rządów - odbywają się one raz do roku na zmianę w Pekinie oraz państwie sprawującym prezydencję w UE ${ }^{32}$. Po stronie Unii w spotkaniach na szczycie uczestniczą Przewodniczący Rady Europejskiej, Przewodniczący Komisji Europejskiej oraz Wysoki przedstawiciel Unii do spraw zagranicznych i polityki bezpieczeństwa, a także ministrowie i komisarze. Po stronie chińskiej udział bierze Premier oraz właściwi ministrowie. Na zakończenie szczytów wydawane są wspólne oświadczenia, określające uzgodnione stanowiska polityczne w zakresie zagadnień dwustronnych, regionalnych i globalnych ${ }^{33}$;

- coroczne spotkania Przewodniczącego wraz z członkami Komisji i Premiera Chin razem z członkami Rady Państwa (tzw. executive-to-executive meetings);

- regularny dialog strategiczny i w sprawach polityki zagranicznej między Wysokim przedstawicielem Unii do spraw zagranicznych i polityki bezpieczeństwa i chińskim ministrem spraw zagranicznych;

- spotkania w razie potrzeby z udziałem Wysokiego przedstawiciela Unii do spraw zagranicznych i polityki bezpieczeństwa i ministra spraw zagranicznych Chin w czasie corocznych spotkań Zgromadzenia Ogólnego Narodów Zjednoczonych;

- coroczne spotkania Dyrektorów Politycznych (na zmianę w Pekinie i Brukseli);

- coroczne spotkania unijnego Dyrektora do spraw Azji i Pacyfiku oraz jego chińskiego odpowiednika (na zmianę w Pekinie i Brukseli);

- posiedzenia odbywające się co najmniej raz w roku z udziałem unijnych i chińskich ekspertów do spraw bezpieczeństwa międzynarodowego, kontroli zbrojeń, nieproliferacji oraz kontroli eksportu;

- posiedzenia odbywające się co najmniej raz w roku z udziałem unijnych i chińskich ekspertów do spraw kontroli handlu bronią strzelecką i bronią lekką;

— spotkania odbywające się raz na pół roku z udziałem ministra spraw zagranicznych Chin i ambasadora UE w Pekinie;

— spotkania odbywające się raz na pół roku z udziałem Wysokiego przedstawiciela Unii do spraw zagranicznych i polityki bezpieczeństwa i ambasadora Chin przy $\mathrm{UE}^{34}$.

Bieżący dialog polityczny prowadzony jest przez unijną Trójkę (przeszłą, urzędującą i przyszłą Prezydencję) oraz Komisję Europejską. W Pekinie Unia reprezentowana jest przez delegację UE, która pełni funkcje dyplomatyczne wobec władz chińskich ${ }^{35}$.

\footnotetext{
32 2. szczyt - Pekin, 21 XII 1999; 3. szczyt - Pekin, 24 X 2000; 4. szczyt - Bruksela, 5 IX 2001; 5. szczyt - Kopenhaga, 24 IX 2002; 6. szczyt - Pekin, 28 X 2003; 7. szczyt - Haga, 8 XII 2004; 8. szczyt - Pekin, 5 IX 2005; 9. szczyt - Helsinki, 9 IX 2006; 10. szczyt - Pekin, 28 XI 2007; 11. szczyt - Praga, 20 V 2009 (przesunięty z 1 XII 2008 w związku z wizytą w państwach UE Dalajlamy); 12. szczyt - Nanjing, 30 XI 2009.

${ }^{33}$ Zob. szerzej: EU-China Summits, China, European Union - EEAS (European External Action Service), http://eeas.europa.eu/china/summits_en.htm, 25 I 2011.

${ }^{34}$ EU-China Political Dialogue, China \& the EU, Delegation of the European Union to China, http://ec.europa.eu/delegations/china/eu_china/political_relations/pol_dialogue/index_en.htm, 29 I 2011.

${ }^{35}$ Zob. szerzej: Delegation of the European Union to China, http://ec.europa.eu/delegations/china/index_en.htm, 29 I 2011.
} 
Dla UE oraz ChRL coraz korzystniejsze staje się wspólne rozwiązywanie problemów politycznych oraz promowanie zrównoważonego rozwoju, pokoju i bezpieczeństwa oraz światowego dobrobytu. Z uwagi na wspólne interesy geopolityczne Unia oraz Chiny powinny podejmować wspólne przedsięwzięcia w skali globalnej, do których włączane mogą być państwa trzecie lub regiony. Przykładem takiego podejścia jest inicjatywa unijna dotycząca trójstronnej współpracy między UE, ChRL oraz Afryką przedstawiona w komunikacie Komisji z 17 października 2008 roku pt. UE, Afryka i Chiny: w kierunku trójstronnego dialogu i współpracy (The EU, Africa and China: Towards trilateral dialogue and cooperation). W dokumencie tym przewidziano nowe formy współpracy pomiędzy jednoczącą się Europą a Państwem Środka, które mogą przyczynić się do rozwoju kontynentu afrykańskiego. Współpraca unijno-chińska w Afryce powinna skupiać się na obszarach mających kluczowe znaczenie dla stabilności i rozwoju regionu. Należą do nich: pokój i bezpieczeństwo; wspieranie infrastruktury; zrównoważona gospodarka zasobami środowiska i zasobami naturalnymi; rolnictwo i bezpieczeństwo żywności. Istotnym aspektem kooperacji Unii i Chin na kontynencie afrykańskim jest także dialog w ramach polityki rozwojowej i partnerstwo na rzecz rozwoju. Do wiodących zasad współpracy zaliczono: pragmatyczną i postępową koncepcję działania, wspólne podejście oraz skuteczną pomoc ${ }^{36}$.

Ważnym aspektem unijno-chińskiego dialogu politycznego jest współpraca w dziedzinie bezpieczeństwa międzynarodowego. Oba podmioty zainteresowane są pokojowym rozwojem współczesnych stosunków międzynarodowych, popierają zatem inicjatywy mające na celu stabilizację bezpieczeństwa międzynarodowego, zarówno w wymiarze globalnym, jak również regionalnym. W szczególności zainteresowanie stron wzbudza kontrola zbrojeń, zwłaszcza problem proliferacji broni jądrowej oraz handel bronią. UE i ChRL prowadzą regularne konsultacje na szczeblu ekspertów w tym zakresie. W czerwcu 2010 roku miała miejsce pierwsza sesja unijno-chińskiego dialogu na temat broni strzeleckiej i lekkiej. Podejmowane są także wspólne wysiłki w walce z piractwem (m.in. w Zatoce Adeńskiej) ${ }^{37}$.

$\mathrm{Na}$ efektywność unijno-chińskiego partnerstwa strategicznego na płaszczyźnie bezpieczeństwa międzynarodowego rzutuje embargo UE na sprzedaż broni do ChRL, wprowadzone 27 czerwca 1989 roku po wydarzeniach na Placu Tiananmen. W latach 2003-2005 Unia wyrażała polityczną wolę jego zniesienia (głównie Francja, Belgia, Hiszpania, Włochy i Niemcy w okresie rządów kanclerza Gerharda Schrödera), co było motywowane głównie względami ekonomicznymi. W rezultacie byłoby możliwe zwiększenie wymiany handlowej o dziedzinę uzbrojenia, a w dłuższej perspektywie, zdaniem zwolenników tego kroku, pogłębienie procesu reform i stabilizacja w regionie. Przeciwko zniesieniu embarga opowiadają się głównie unijne państwa neutralne, bądź prowadzące politykę neutralności, przede wszystkim Dania, Holandia i Wielka Brytania. Argumentem przemawiającym za utrzymaniem zakazu obrotu sprzętem wojskowym jest agresywna polityka rządu w Pekinie wobec Tajwanu oraz kwestia łamania przez Chiny praw człowieka, w tym mniejszości narodowych - Tybetańczyków oraz Ujgurów. Istotnym jest również sprzeciw USA w odniesieniu do zniesienia unijnego embar-

\footnotetext{
${ }^{36}$ Zob. szerzej: Komunikat Komisji do Rady, Parlamentu Europejskiego, Europejskiego Komitetu Ekonomiczno-Społecznego i Komitetu regionów, UE, Afryka i Chiny: w kierunku trójstronnego dialogu i wspótpracy, COM (2008), 0654 końcowy, http://ec.europa.eu/development/icenter/repository/COMM_PDF_COM_2008_0654_F_COMMUNICATION_pl.pdf, 29 I 2011.

${ }^{37}$ Factsheet EU-China Summit, EU policy towards China, China, European Union - EEAS (European External Action Service), http://www.consilium.europa.eu/uedocs/cms_data/docs/pressdata/en/er/116848.pdf, 29 I 2011.
} 
ga. Pojawia się także problem sprzedaży przez Chiny europejskich technologii wojskowych stronom trzecim ${ }^{38}$.

Kwestia zniesienia europejskiego embarga na sprzedaż broni do ChRL „odżyła” pod koniec 2010 roku. Za francuskim dziennikiem „Le Figaro”, powołującym się na źródło z otoczenia C. Ashton, światowe portale informacyjne obiegła wiadomość o możliwym zniesieniu embarga przez Unię w 2011 roku. Jednak z uwagi na duże rozbieżności w tej kwestii między państwami unijnymi, a równocześnie wymagany konsensus w celu podjęcia decyzji, na chwilę obecną zniesienie embarga nie jest możliwe ${ }^{39}$.

\section{Dialog na płaszczyźnie praw człowieka}

Dla jednoczącej się Europy problem demokratyzacji Chin jest jednym z głównych priorytetów. Zasadnicze znaczenia dla relacji bilateralnych ma wspieranie przemian w Państwie Środka w kierunku otwartego społeczeństwa i rządów prawa. UE posiada możliwości wpływania na tej płaszczyźnie na reżim w Pekinie przy pomocy instrumentów z zakresu miękkiej siły: kontaktów gospodarczych, współpracy naukowej i kulturalnej, a także turystyki. Kwestie demokratyzacji Chin i prawa jednostki są dyskutowane w ramach dialogu politycznego oraz w zakresie ustanowionego w 1995 roku Dialogu na temat Praw Człowieka, a także Spotkań Unijno-Chińskiego Okragłego Stołu w zakresie Społeczeństwa Obywatelskiego (EU-China Civil Society Round Table) - pierwsze spotkanie odbyło się 22 czerwca 2007 roku w Pekinie. Inicjatywy te realizowane są w formie odbywających się dwa razy do roku (raz na każdą prezydencję) spotkań na szczeblu wyższych urzędników. Poruszane tematy to m.in. ratyfikacja przez Chiny Międzynarodowego Paktu Praw Obywatelskich i Politycznych (International Covenant on Civil and Political Rights - ICCPR), wolność mediów, problem kary śmierci i tortur, reedukacja przez pracę, prawa mniejszości narodowych.

Komisja Europejska wpiera inicjatywę Seminariów Praw Człowieka z udziałem europejskich i chińskich ekspertów w celu wymiany poglądów i doświadczeń. Realizowany jest Program Unijno-Chińskiej Współpracy Prawnej i Sądowej, który jest zdecydowanie najważniejszym projektem pomocy zagranicznej dla Chin mającej na celu wzmocnienie rządów prawa. Inicjatywą zmierzającą do przyznania obywatelom chińskim praw obywatelskich na poziomie lokalnym (socjalnych i ekonomicznych) jest Program Rządowy Unijno-Chińskich Wiosek (EU-China Village Governance Programme) realizowany w prowincji Yunnan. Obecnie Komisja Europejska wdraża we współpracy z UNDP inicjatywę Zarządzanie dla Sprawiedliwego Rozwoju (Governance for Equitable Development). Projekt ma na celu wzmocnienie państwa prawa i rozwoju społeczeństwa obywatelskiego w Chinach, poprzez promowanie uczestnictwa i włączenia społeczeństwa do wybranych procesów legislacyjnych, sądowych i rządowych ${ }^{40}$.

Praktyczny wymiar realizacji unijno-chińskiego dialogu w odniesieniu do praw człowieka napotyka na szereg przeszkód. Na tej płaszczyźnie uwidacznia się brak zgodności poszczególnych państw członkowskich UE, co do priorytetów wzajemnej współpracy. W przypadku

\footnotetext{
${ }^{38}$ Zob. szerzej: K. Hołdak, A. Konarzewska, op. cit., s. 282-289.

${ }^{39} \mathrm{~K}$. Niklewicz, Chińskie wojsko nie dostanie europejskiej broni, Wyborcza.biz, http://wyborcza.biz/biznes/1,101562,8913868,Chinskie_wojsko_nie_dostanie_europejskiej_broni.html, 29 I 2011.

${ }^{40}$ Human Rights Dialogue, $\bar{C}$ hina $\&$ the $\overline{E U}$, Delegation of the European Union to China, http://ec.europa.eu/delegations/china/eu_china/political_relations/humain_rights_dialogue/index_en.htm, 29 I 2011.
} 
dużych państw, w tym Francji, Niemiec, Włoch i Hiszpanii na pierwszym planie znajdują się relacje gospodarcze z Państwem Środka, natomiast problematyka przestrzegania praw człowieka ograniczana jest do minimum. Z kolei przez państwa skandynawskie i Holandię traktowana jest ona jako kluczowa dla dalszego rozwoju unijno-chińskiego partnerstwa. Domagają się one skutecznej polityki w kwestii demokratyzacji Chin i praw człowieka. W konfrontacji wymiana handlowa versus prawa człowieka ciagle jednak zdecydowanie pierwszeństwo ma ta pierwsza ${ }^{41}$.

\section{Nauka i technologia}

Szczególną rolę w relacjach unijno-chińskich odgrywa współpraca na płaszczyźnie naukowo-technologicznej. Zapoczątkowana została ona na początku lat osiemdziesiątych XX wieku. Uległa znacznej intensyfikacji w okresie realizacji 4. i 5., a zwłaszcza 6. Programu Ramowego w zakresie badań i rozwoju technologicznego UE, obowiązującego w latach 1994-2006. Umowę o współpracy unijno-chińskiej w dziedzinie R\&T podpisano w 1998 roku, uzupełniono ją następnie w 2004 i 2009 roku $^{42}$.

W ramach 6. Programu Ramowego zrealizowano 214 wspólnych inicjatyw badawczych z udziałem chińskich przedstawicieli, o łącznym budżecie ponad 1, 1 mld euro, z czego 2/3 sfinansowała $U^{43}$. Obecnie głównym europejskim instrumentem wspierania wspólnych badań naukowych jest 7. Program Ramowy w zakresie badań i rozwoju technologicznego przyjęty na lata 2007-2013, będący największym programem finansowania badań na świecie (budżet wysokości 53,2 mld euro) ${ }^{44}$. Na mocy umowy unijno-chińskiej dla europejskich partnerów otwarte są chińskie programy badawcze: 973 krajowe programy badań podstawowych i 863 krajowe programy badań high-tech ${ }^{45}$. W efekcie Chiny są współcześnie największym partnerem po Stanach Zjednoczonych i Rosji, jeśli chodzi o współpracę Unii z państwami trzecimi w zakresie nauki i technologii. Biorą m.in. udział w realizacji europejskiego systemu nawigacji satelitarnej Galileo.

Wizytówkami współpracy UE-ChRL na płaszczyźnie naukowo-technologicznej w ostatnich latach są:

- Chińsko-europejska Międzynarodowa Szkoła Biznesu (China Europe International Business School - CEIBS) działająca w Szanghaju od połowy lat dziewięćdziesiątych XX wieku ${ }^{46}$ oraz Chińsko-unijna Szkoła Prawa (China-EU School of Law - CESL), funkcjonująca w Pekinie od roku $2008^{47}$;

- Europejsko-chińskie Centrum Czystej Energii EC2 w Pekinie oraz Międzynarodowy Instytut Energii Czystej i Odnawialnej w Wuhan - główne kanały współpracy w dziedzinie energii i zrównoważonego rozwoju;

\footnotetext{
${ }^{41}$ Zob. szerzej: K. Hołdak, A. Konarzewska, op. cit., s. 289-292.

${ }^{42}$ EU-China Relations: Chronology, op. cit.

${ }^{43}$ Science and Technology, China \& the EU, Delegation of the European Union to China, http://ec.europa.eu/delegations/china/eu_china/science_tech_environmement/science_technology/index_en.htm, 30 I 2011.

${ }^{44}$ Zob. szerzej: Siódmy Program Ramowy (7PR), http://ec.europa.eu/research/fp7/pdf/fp7-brochure_pl.pdf,

${ }^{45}$ Science and Technology, op. cit.

${ }^{46}$ Zob. szerzej: China Europe International Business School, http://www.ceibs.edu/index_en.shtml, 30 I 2011.

${ }^{47}$ Zob. szerzej: China-EU School of Law, http://www.cesl.edu.cn/, 30 I 2011.
} 30 I 2011. 
— udział Chin w programie Erasmus Mundus - program „China Window”, z którego sfinansowano studia bliski 1 tys. studentów chińskich w Europie.

\section{Ochrona środowiska naturalnego i problemy energetyczne}

Coraz istotniejszą rolę wśród tematów współpracy UE-ChRL odgrywa dialog na temat ochrony środowiska i problemów energetycznych. Degradacja środowiska naturalnego na skutek przyspieszonej industrializacji w Chinach staje się coraz poważniejszym problemem, z czego zdaje sobie sprawę jednocząca się Europa, będąca głównym odbiorcą chińskich towarów. Również władze w Pekinie postrzegają Unię jako najważniejszego partnera w realizacji celów zrównoważonego rozwoju. Dialog na płaszczyźnie ochrony środowiska dotyczy głównie kwestii zanieczyszczenia atmosfery i wód gruntowych, niekontrolowanego wyrębu lasów, zagrożeń dla różnorodności biologicznej, problemu odpadów oraz awarii przemysłowych. Najwyższy priorytet przyznano współpracy w zakresie globalnych zmian klimatycznych, czego instytucjonalnym wyrazem było ustanowienie w 2005 roku Partnerstwa w sprawie Zmian Klimatycznych. Obie strony wyrażają konieczność negocjacji na temat zmian klimatycznych z uwzględnieniem Panu działań z Bali i Porozumienia z Cancun.

W ostatnich latach unijno-chińska współpraca w dziedzinie energii nabrała znaczenia poprzez zapoczątkowany 30 marca 2006 roku w Wiedniu dialog między Dyrekcją Generalną ds. Transportu i Energii (Directorate-General for Transport and Energy - DG TREN) ${ }^{48}$ a chińską Narodową Komisją Rozwoju i Reform (National Development and Reform Commission - NDRC) - od lata 2008 Narodową Administracją do spraw Energii (National Energy Administration - NEA). Odbyły się wówczas pierwsze dwustronne konsultacje w ramach Partnerstwa w sprawie Zmian Klimatycznych. Współpraca na płaszczyźnie energetycznej koncentruje się głównie na kwestiach zwiększania efektywności energetycznej i odnawialnych źródłach energii, technologiach niskoemisyjnych oraz promowaniu oszczędności energii ${ }^{49}$.

Obok zarządzania sektorem energetycznym w sposób jak najmniej szkodliwy dla środowiska naturalnego, zarówno UE, jak i ChRL posiadają wspólne interesy w odniesieniu do bezpieczeństwa energetycznego, w tym dostępności złóż ropy naftowej i gazu ziemnego, dywersyfikacji ich źródeł, bezpieczeństwa sieci tranzytowych. Oba podmioty z uwagi na niewystarczające zasoby oraz duże zapotrzebowanie zmuszone są do importowania surowców energetycznych. Mimo, że obecnie polityka energetyczna władz w Pekinie nie jest postrzegana jako bezpośrednie zagrożenie dla bezpieczeństwa energetycznego jednoczącej się Europy, bez wattpienia jednak coraz większe wyzwanie w skali globalnej stanowi dynamiczny wzrost zapotrzebowania chińskiej gospodarki na nośniki energii. W 1993 roku Chiny stały się importerem netto surowców energetycznych; w ostatnich latach głównie na skutek rozwoju produkcji przemysłowej dramatycznie rośnie ich konsumpcja, przede wszystkim ropy naftowej. W rezultacie ChRL będąc piątym na świecie producentem ropy naftowej jest jej trzecim po USA i UE globalnym konsumentem (zob. tab. 9). Według danych za 2009 rok chińskie spoży-

\footnotetext{
${ }^{48}$ W 2010 roku podzielona na Dyrekcję Generalną do spraw Mobilności i Transportu (Directorate-General for Mobility and Transport - DG MOVE) oraz Dyrekcję Generalną do spraw Energii (Directorate-General for Energy - DG Ener).

${ }^{49}$ Energy, China \& the EU, Delegation of the European Union to China, http://ec.europa.eu/delegations/china/eu_china/science_tech_environmement/energy/index_en.htm, 30 I 2011.
} 
cie tego surowca było ponad dwukrotnie wyższe niż możliwości produkcyjne, przy czym proporcje te z roku na rok się zwiększają. Jest to istotny fakt dla jednoczącej się Europy, w której uzależnienie od zagranicznych zakupów jest o wiele większe. W 2007 roku rodzima produkcja ropy naftowej zaspokajała jedynie $17,4 \%$ zapotrzebowania $^{50}$.

Tabela 9

Ranking państw świata - produkcja i konsumpcja ropy naftowej w roku 2009

\begin{tabular}{|c|c|c|c|c|}
\hline \multirow{2}{*}{$\begin{array}{c}\text { Miejsce } \\
\text { w rankingu }\end{array}$} & \multicolumn{2}{|c|}{ Produkcja } & \multicolumn{2}{|c|}{ Konsumpcja } \\
\hline & państwo & mln barylek dziennie & państwo & mln baryłek dziennie \\
\hline 1 & Rosja & 10,120 & USA & 18,690 \\
\hline 2 & Arabia Saudyjska & 9,764 & UE & $\begin{array}{l}13,680 \\
(2007)\end{array}$ \\
\hline 3 & USA & 9,056 & Chiny & 8,200 \\
\hline 4 & Iran & 4,172 & Japonia & 4,363 \\
\hline 5 & Chiny & 3,991 & Indie & 2,980 \\
\hline
\end{tabular}

Źródło: Oprac. własne na podstawie: Country comparison: Oil - Consumption, CIA World Factbook, https://www.cia.gov/library/publications/the-world-factbook/rankorder/2174rank.html, 1 II 2011; Country comparison: Oil - Production, CIA World Factbook, https:/www.cia.gov/library/publications/the-world-factbook/rankorder/2173rank.html, 1 II 2011.

\section{Problem spójność unijnej polityki}

Podsumowując praktyczną realizację założeń strategicznego partnerstwa między Unią Europejską a Chińską Republiką Ludową należy wskazać na kluczowy problem w relacjach jednoczącej się Europy z Państwem Środka, podobnie zresztą jak w przypadku stosunków ze Stanami Zjednoczonymi czy Federacją Rosyjską, a mianowicie nieumiejętność „mówienia jednym głosem" i to często na płaszczyznach stanowiących sedno wzajemnej współpracy. W relacjach z Chinami ciągle większe znaczenie mają bilateralne stosunki poszczególnych państw członkowskich niż relacje z nimi Unii jako całości. Różnice zdań między państwami unijnymi są przy tym skrupulatnie wykorzystywane przez władze ChRL, który umiejętnie je rozgrywają do realizacji własnych interesów. Najbardziej pożądana z ich punktu widzenia jest rywalizacja poszczególnych członków UE o chiński rynek. W tej sytuacji reżimowi w Pekinie przypada rola arbitra, który nagradza posłusznych i karci niepokornych ${ }^{51}$. Zasadniczą kwestią pozostają zatem koordynacja i spójność polityk narodowych poszczególnych państw unijnych oraz stosowanie w praktyce przyjętych wspólnie priorytetów. W przypadku tak poważnego partnera gospodarczego, jakim jest ChRL, dochodzenie do kompromisu jest jednak w szczególności utrudnione, z uwagi na rozbieżności interesów między państwami członkowskimi UE, o czym świadczy chociażby kwestia embarga na dostawy broni do Chin.

Jednak z punktu widzenia jednoczącej się Europy spójna strategia wobec Państwa Środka ma kluczowe znaczenie, z uwagi na wzrost jego potęgi oraz skali międzynarodowego oddziaływania.

\footnotetext{
${ }^{50}$ European Union, CIA World Factbook, https://www.cia.gov/library/publications/the-world-factbook/geos/ee.html, 1 II 2011.

${ }^{51}$ Wystapienie Pana Ministra Radostawa..., op. cit.
} 
Na początku drugiej dekady XXI wieku pozycja międzynarodowa Chińskiej Republiki Ludowej znacznie się umocniła. Światowy kryzys gospodarczy, który w dużym stopniu spowolnił gospodarki państw wysokorozwiniętych osłabił wprawdzie tempo wzrostu gospodarczego Państwa Środka, ale go nie zahamował. W rezultacie chińska gospodarka stała się drugą gospodarką współczesnego świata, ustępując jedynie amerykańskiej i wyprzedzając znacznie pozostałe mocarstwa. Dzięki wzrostowi gospodarczemu chińska polityka zagraniczna zyskała na znaczeniu, stając się bardziej aktywną i wyrafinowaną. Opiera się ona przede wszystkim na dążeniu do zapewnienia odpowiedniego wzrostu gospodarczego i zajęcia miejsca w świecie, które odzwierciedlałoby rosnący potencjał polityczny oraz gospodarczy Chin. Po latach marginalizacji powracają one do grona wielkich mocarstw, co w pełni dostrzeżone zostało przez Unię Europejską, będącą także mocarstwem in spe. Dlatego wzrost międzynarodowego znaczenia ChRL będąc bez wątpienia wyzwaniem dla jednoczącej się Europy jest równocześnie postrzegany jako szansa pokojowego rozwoju, zarówno dla samej Unii, jak również systemu międzynarodowego.

Z uwagi na potencjały i rosnącą siłę oddziaływania międzynarodowego UE oraz ChRL wzajemne relacje między nimi mają priorytetowe znacznie dla obu podmiotów, czego wyrazem było przyznanie im rangi kompleksowego strategicznego partnerstwa. Analiza instytucjonalnej płaszczyzny wzajemnych relacji unijno-chińskich wskazuje, że jego zakres przedmiotowy ulega systematycznemu rozszerzaniu o nowe płaszczyzny oraz instrumenty współpracy. Pierwotnie dotyczyła ona jedynie wąsko pojętych kwestii handlowych i pomocy rozwojowej; stopniowo zaczęła obejmować całokształt problematyki gospodarczej. Po zakończeniu zimnej wojny kluczowym elementem wzajemnych stosunków stał się dialog polityczny w wymiarze strategicznym, a także w zakresie praw człowieka i standardów demokratycznych; nowego wymiary nabrała współpraca naukowo-technologiczna. Na początku drugiej dekady XXI wieku położono nacisk na kwestie wzajemnej kooperacji kulturowej i kontakty międzyludzkie.

Oceniając realizację założeń partnerstwa strategicznego łączącego UE z ChRL należy zwrócić uwagę na następujące kwestie: dynamiczny wzrost wartości wymiany handlowej, rosnące znaczenie dialogu politycznego oraz rozwój współpracy sektorowej. Mimo iż współcześnie relacje unijno-chińskie wykraczają dalece poza kwestie gospodarcze, jednak ciągle to właśnie ta płaszczyzna stanowi główny ciężar stosunków bilateralnych. Dla jednoczącej się Europy Państwo Środka jest drugim, co do ważności partnerem gospodarczym - pierwszym pod względem importu i trzecim biorąc pod uwagę wartość eksportu. Z punktu widzenia Chin Unia jest trzecim największym partnerem gospodarczym. Strukturę wzajemnej wymiany handlowej określa znaczny deficyt po stronie unijnej. Oba podmioty są dla siebie znaczącymi źródłami bezpośrednich inwestycji zagranicznych. UE jest drugim najważniejszym inwestorem zagranicznym w ChRL; w ostatnich latach systematycznie rosną również chińskie inwestycje w państwach europejskich.

Obecnie płaszczyzny stosunków bilateralnych unijno-chińskich dalece wykraczają poza instrumenty dawnego pierwszego filaru. Obie strony dostrzegają fakt posiadania wspólnych interesów geopolitycznych i są zgodne, co do pogłębiania dialogu politycznego i rozszerzania go na nowe płaszczyzny. W wymiarze strategicznym najważniejszymi kwestiami dla UE i ChRL jest multipolarny wymiar ładu międzynarodowego i zrównoważony rozwój. W interesie obu podmiotów leży umacnianie regionalnego i globalnego bezpieczeństwa i pokojowy rozwój stosunków międzynarodowych, poprzez ograniczanie proliferacji broni jądrowej oraz 
regulacje handlu bronią. Problemami szczególnie zajmującymi partnerów są globalne zmiany klimatyczne, kwestie energetyczne i ochrona środowiska naturalnego. Poszerza się zakres współpracy w zakresie nauki i technologii - Chiny współcześnie są trzecim w kolejności najważniejszym unijnym partnerem na tej płaszczyźnie.

Obok wspólnoty interesów w relacjach unijno-chińkich nie brakuje rozbieżności. Do nierozwiązanych problemów zaliczają się zarówno zagadnienia polityczne, jak również gospodarcze. Do tych pierwszych należą w pierwszej kolejności naruszanie wolności słowa i wyznań przez reżim w Pekinie oraz brak standardów demokratycznych, bezpieczeństwo w Cieśninie Tajwańskiej, czy też sprawa zniesienia unijnego embarga na handel uzbrojeniem z ChRL. Różnice interesów w kwestiach gospodarczych wiążą się głównie z przyznaniem Chinom statusu gospodarki wolnorynkowej. Istotnymi problemami są także nieprzestrzegania praw własności intelektualnej oraz ochrona rynku europejskiego przed zalewem tanich i niskiej jakości wyrobów chińskich.

W coraz większej liczbie spraw związanych z realizacją założeń partnerstwa strategicznego unijno-chińskiego decyzje zapadają w Brukseli. Mimo wszystko jednak w stosunkach z Państwem Środka ciagle ważniejszą rolę odgrywają relacje dwustronne poszczególnych państw członkowskich Unii. Aby powrót ChRL do grona wielkich mocarstw stanowił szansę, a nie zagrożenie dla jednoczącej się Europy, należy mieć na uwadze, że staje się ona jednym z najważniejszych graczy na scenie międzynarodowej w wymiarze zarówno gospodarczym, jak również politycznym. Jedynie silna, zjednoczona i „mówiąca jednym głosem” Europa może być równoprawnym i wiarygodnym partnerem dla Państwa Środka oraz stanowić przeciwwagę dla jego rosnących globalnych wpływów.

\section{Summary}

\section{The dynamics of mutual relations between the European Union and the People's Republic of China at the beginning of the $21^{\text {st }}$ century}

On account of their potential, and the growing international influence of the EU and the People's Republic of China, the mutual relations of both parties conducted at the level of a complex strategic partnership are a priority for both of them. The scope of the said partnership is consistently expanding and includes new dimensions and instruments of cooperation. Modern relations between the EU and China go far beyond the economic issues which, nevertheless, remain the main part of bilateral relations. Still, both parties have noted that they have common geopolitical interests and they are in agreement that political dialogue should deepen and expand.

The common interests in EU-Chinese relations are accompanied by a number of divergent ones. The main discrepancy concerns political issues (lack of democratic standards, violation of freedom and civil rights, and the EU's embargo on weapons) as well as economic ones (the free market status of the Chinese economy and the violation of intellectual property laws by China).

From the point of view of the European Union, particular significance in relations with China should be given to the coordination and cohesion of national policies conducted by individual Member States and to the practical application of commonly agreed priorities. Only an EU speaking with a single voice can be a credible and significant partner for China, which after the years of being marginalized is returning to the circle of great powers of the modern world. 